\title{
A Dinâmica do Mercado de Trabalho Formal do Setor Sucroalcooleiro Paranaense de 2000-2017 Evolução dos Empregos e Perfil dos Trabalhadores
}

http://dx.doi.org/10.21527/2237-6453.2020.53.386-407

Recebido em: $17 / 4 / 2020$

Aceito em: 8/9/2020

\author{
Edna Marta Pelosi, ${ }^{1}$ Pery Francisco Assis Shikida²
}

\begin{abstract}
RESUMO
Este artigo analisa a dinâmica do mercado de trabalho formal do setor sucroalcooleiro paranaense no período de 2000 a 2017, considerando a geração dos empregos e o perfil dos trabalhadores, a partir da Relação Anual de Informações Sociais (Rais) e do Cadastro Geral de Empregados e Desempregados (Caged). Os trabalhadores foram classificados intrasetorialmente por meio da atividade que exercem, sendo utilizadas as categorias da Classificação Brasileira de Ocupações (CBO) para distinguir os trabalhadores agrícolas dos demais. Os dados apontam para um expressivo aumento no número de empregos entre 2000 e 2009, principalmente os relacionados às atividades agrícolas, além de uma contínua retração depois de 2009, com destaque novamente para as atividades agrícolas. Neste último período foram constatadas alterações significativas no perfil do trabalhador: mais velho, mais bem instruído e mais bem remunerado com relação aos períodos anteriores.
\end{abstract}

Palavras-chave: Empregos. Açúcar. Álcool. Paraná.

\section{THE DYNAMICS OF THE FORMAL LABOR MARKET OF THE SUGAR AND ALCOHOL INDUSTRY OF PARANÁ FROM 2000 TO 2017: EMPLOYMENT EVOLUTION AND PROFILE OF WORKER}

\section{ABSTRACT}

This paper analyzes the dynamics of the formal labor market of the sugar and alcohol industry of Paraná from 2000 to 2017, considering the jobs' creations and the profile of workers, based on the Annual List of Social Information (Rais) and the General Register of Employed and Unemployed Persons (Caged). The workers were classified intrasetorially, through their activity, by using the Brazilian Classification of Occupations (CBO) categories to highlight the agricultural workers of the others. The data shows to a significant increase in the number of jobs between 2000 and 2009, especially those related to agricultural activities, in addition to a continuous decline after 2009, with a particular highlight of farming activities. In this last period there were significant changes in the profile of the worker: older; better-educated and better-paid compared to previous periods.

Keywords: Jobs. Sugar. Alcohol. Paraná.

\footnotetext{
${ }^{1}$ Mestre em Administração pela Universidade Estadual de Londrina (UEL). Servidora da Universidade Tecnológica Federal do Paraná (UTFPR). http://lattes.cnpq.br/3220039022915941. https://orcid.org/0000-0001-8021-863X. ednapelosi@gmail.com

${ }^{2}$ Doutor em Economia Aplicada pela Universidade de São Paulo (USP). Professor da Universidade Estadual do Oeste do Paraná (Unioeste). http://lattes.cnpq.br/1740467499247374.https://orcid.org/0000-0001-9621-1520. peryshikida@hotmail.com
} 
O Brasil é o maior produtor mundial de cana-de-açúcar e sua cadeia sucroenergética destaca-se no contexto do agronegócio e da economia brasileira. Tendo produzido na safra 2017/2018 641 milhões de toneladas de cana-de açúcar, 38,6 milhões de toneladas de açúcar e 27,9 milhões de metros cúbicos de etanol, o país ocupa papel relevante no mercado internacional, sendo o segundo na produção de etanol (a produção alcooleira dos Estados Unidos, à base de milho, é a única que supera a produção nacional) e o primeiro na produção de açúcar até o ano de 2018 (segundo estimativas para a safra 2018/2019, o país pode perder sua hegemonia de 16 anos para a Índia, que o superará em produção, porém ainda mantém a posição de principal exportador). A lavoura canavieira ocupa 10,2 milhões de hectares (safra 2017/2018) e, em razão de suas especificidades geográficas e edafoclimáticas, a produção ocorre tanto nas regiões Sul, Sudeste, Centro-Oeste e Norte-Nordeste, possibilitando duas safras anuais para atender à demanda interna e externa (dados extraídos de UNICA, 2019a; CONAB, 2018).

Assim, o setor sucroalcooleiro contribui enormemente para a geração de divisas e geração de emprego e renda. Quanto à geração de divisas, na safra 2017/2018, segundo a União da Indústria de Cana-de-Açúcar (UNICA, 2019b), a exportação de açúcar gerou receitas na ordem de 10 bilhões de dólares, enquanto a exportação de etanol atingiu 810 milhões. Já no que se refere à criação de empregos, foco deste artigo, segundo dados do Centro de Estudos Avançados em Economia Aplicada (CEPEA, 2018), 3,2\% do total de pessoas ocupadas no agronegócio em 2017 estavam em atividades da cadeia sucroalcooleira, que apresenta também alto nível de formalização: $80 \%$ para os trabalhadores das atividades agrícolas ante $17 \%$ na agricultura de modo geral; e $95 \%$ na agroindústria (usinas de açúcar e álcool), enquanto para a agroindústria em geral esse percentual é de $58 \%$.

Os números apresentados anteriormente devem-se a importantes transformações institucionais pelas quais passou o setor sucroalcooleiro nas últimas décadas. No período pós-década de 90 , uma sucessão de fatores como a desregulamentação da atividade, o surgimento dos veículos biocombustíveis, bem como uma melhora no cenário internacional e aumento na demanda externa, contribuiram para a modernização do setor consequente expansão da área plantada e da produção do açúcar e etanol (FERNANDES; SHIKIDA; CUNHA, 2013). Estes fatores contribuiram para a transformação da geografia da cana-de-açúcar e impactaram diretamente na demanda e condições das ocupações geradas em suas atividades.

Neste sentido, no que respeita à alteração geográfica da produção sucroalcooleira nacional, as transformações em termos de desregulamentação e redução de subvenções favoreceram a entrada de outros Estados que não faziam parte desse mercado, mas que dispunham de condições econômicas e edafoclimáticas substanciais para atrair o capital canavieiro. A produção de cana-de-açúcar, antes concentrada em Minas Gerais, São Paulo, Rio de Janeiro e faixa litorânea nordestina, passou a se difundir e/ou se intensificar em Estados como o Paraná, Mato Grosso do Sul e Goiás, que já em 2009 superavam o Rio de Janeiro e outros Estados do Nordeste na produção de cana-de-açúcar e geração de empregos (FERNANDES; SHIKIDA; CUNHA, 2013). 
A partir de 2009, porém, iniciou-se um período de crise e maior cautela de investimentos resultando, inclusive, no fechamento de diversas unidades. Tais acontecimentos foram consequência de fatores como a política de uso dos preços da gasolina para controle inflacionário, baixa previsibilidade de políticas energéticas, desonerações promovidas sobre os combustíveis fósseis, entre outros aspectos (CEPEA, 2018). Somando-se a estes fatores, o processo de mecanização, principalmente da colheita da cana-de-açúcar, que atualmente atinge praticamente $95 \%$ dos canaviais na região Centro-Sul, segundo dados da Companhia Nacional de Abastecimento (CONAB, 2018), impactou diretamente na geração de empregos voltados às atividades agrícolas, conforme mencionado por diversas pesquisas realizadas no período de expansão do setor (MORAES, 2007; ESTANISLAU; DEON; SHIKIDA, 2008; DELGADO, 2012).

Desta forma, no período de expansão da atividade sucroalcooleira, entre 2000 e 2008, o número de empregos formais gerados pelo setor, em âmbito nacional, teve um aumento expressivo de quase 100\%. A partir de 2008 até o ano de 2016 o setor passou a registrar queda constante na geração de empregos de aproximadamente $38 \%$, com notável perda de postos de trabalho na região Centro-Sul (40,3\%), mais intensiva em mecanização (CEPEA, 2018).

Nesse contexto, este artigo busca analisar a dinâmica do mercado de trabalho formal do setor sucroalcooleiro no Estado do Paraná de 2000 a 2017, com o objetivo de trazer uma base de dados atualizada sobre a evolução e as transformações em termos de demanda e perfil da mão de obra empregada no setor, ao mesmo tempo que propõe uma reflexão sobre o impacto de aspectos institucionais e conjunturais nesse mercado. A base de dados utilizada no estudo contempla os empregos formais do setor e é proveniente da Relação Anual de Informações Sociais (RAIS) e do Cadastro Geral de Empregados e Desempregados (Caged).

Diferentemente de outros estudos já realizados sobre o mercado de trabalho no setor, que fizeram uso apenas das classificações relativas às atividades fins das empresas contratantes (Cnae) para classificar os trabalhadores entre os diferentes elos de atividade dentro da cadeia, esta pesquisa utiliza-se também da Classificação Brasileira de Ocupações (CBO). Como bem observam pesquisadores do Cepea (2018), dada a elevada verticalização do setor, a classificação dos trabalhadores com base apenas nas Cnaes da atividade principal da empresa contratante leva a equívocos de interpretação, especialmente em relação aos trabalhadores de atividades agrícolas, que podem ser classificados como trabalhadores do elo industrial do setor, impactando em superestimação dos empregos nos elos industriais e subestimando as ocupações no campo. Assim, esta metodologia oferece resultados mais próximos à realidade da cadeia sucroalcooleira.

Além desta introdução o artigo está organizado em mais quatro seções. Depois de uma breve revisão de literatura sobre a evolução do setor sucroalcooleiro paranaense, tem-se um panorama da situação atual do setor, destacando seu posicionamento em âmbito nacional em termos de área plantada e produção, bem como sua participação na indústria paranaense. Na quarta seção tem-se a análise dos dados sobre a evolução da geração de empregos ao longo das duas últimas décadas e as mudanças no perfil dos trabalhadores. Por fim, são apresentadas as considerações finais. 


\section{A EVOLUÇÃO DO SETOR SUCROALCOOLEIRO PARANAENSE: ASPECTOS INSTITUCIONAIS E OS EFEITOS DA MECANIZAÇÃO NO MERCADO DE TRABALHO}

Nos seus primórdios, o Paraná não apresentava nenhuma expressão em termos de cultura canavieira. $O$ açúcar produzido no Estado era insuficiente até mesmo para atender à demanda interna, mostrando-se comum a necessidade de importação do produto, principalmente do vizinho Estado de São Paulo, até o início da década de 70. Pelas suas relativas condições edafoclimáticas, contudo, e proximidade do eixo canavieiro de São Paulo, a cultura da cana-de-açúcar encontrou condições favoráveis para o seu desenvolvimento, principalmente após a crise da economia cafeeira na região norte do Paraná. A necessidade de um melhor aproveitamento das terras com culturas mais rentáveis e, da mesma forma, a urgência de um melhor equilíbrio entre demanda e oferta de açúcar, foram elementos fundamentais para que investimentos de grupos açucareiros paulistas fossem canalizados para o Paraná, dando um primeiro impulso de crescimento à cultura no Estado (SHIKIDA; ALVES, 2001).

A cultura canavieira paranaense, tendo seu primeiro impulso na década de 70, foi alavancada definitivamente com o Programa Nacional do Álcool (Proálcool), cujos investimentos, voltados ao estímulo da produção e uso do álcool como combustível em substituição à gasolina - em suas primeiras fases (1975 a 1979 e 1980 a 1985) - além de promover a expansão das unidades industriais no país, por meio de forte subvencionismo estatal, garantiram preços e mercado ao setor (SHIKIDA; BACHA, 1999). ${ }^{3}$ Nesse contexto, conforme assinalam Shikida et al (2008), principalmente em sua segunda fase, o Programa impulsionou o desenvolvimento de novas regiões produtoras, notadamente no Paraná, Goiás, Mato Grosso e Mato Grosso do Sul.

Assim, o incentivo dado pelo Proálcool e, mais tarde, o ambiente proporcionado pela desregulamentação setorial, na última fase do Programa, são dois fatores primordiais para explicar o crescimento da produção canavieira no Paraná (SHIKIDA et al., 2008). Dessa forma, se nas primeiras fases o crescimento do setor no Estado deu-se por intermédio de forte subvenção, na última fase, de desregulamentação do setor - que se deu no contexto de abertura ao mercado internacional e globalização da economia - a manutenção e crescimento de forma sustentável de usinas e destilarias passou a depender da capacidade de investimentos em tecnologia e competências por parte das próprias empresas. Isso porque, paralelamente às fortes pressões competitivas provocadas pela rápida abertura comercial, estava em curso a readequação da economia para se ajustar à crise fiscal do Estado brasileiro, refletindo diretamente em redução da disponibilidade de recursos para as políticas setoriais destinadas a estimular a agropecuária e os setores agroindustriais (STADUTO; SHIKIDA; BACHA, 2004).

${ }^{3}$ Sobre o lançamento do Programa Nacional do Álcool (Proálcool), ver em Shikida e Bacha, 1999. 
Conforme explicam Vian e Belik (2003), com a extinção do Instituto do Açúcar e do Álcool (IAA) em 1990, ${ }^{4}$ as práticas de intervenção e planejamento estatal que caracterizavam o setor até então, e que Shikida (2014) denomina de "paradigma subvencionista, como as cotas de produção e exportação, subsídios e controle da instalação de novas unidades, deixaram de ser praticadas, emergindo uma estrutura com aspectos técnicos e organizacionais mais afinados com a perspectiva da competição, ou como se refere Shikida (2014), "novo paradigma tecnológico". Ainda para Vian e Belik (2003), um dos primeiros impactos da desregulamentação foi a descentralização da produção do açúcar, a qual o Estado do Paraná, dada a eficiente organização de seus produtores, soube aproveitar muito bem. Na safra 91/92 cinco destilarias autônomas do Paraná diversificaram suas atividades, passando a produzir açúcar e álcool. Quatro anos depois já eram 13 as empresas produtoras e na safra 99/2000, 18 unidades. ${ }^{5}$

Assim, a desregulamentação do setor sucroalcooleiro, somada à abertura da economia brasileira, provocou mudanças na estrutura do mercado, no sistema de produção e na forma como a cadeia produtiva sucroalcooleira estava organizada, impulsionando seu crescimento. $O$ setor passou por um processo de concentração, por meio de fusões e aquisições de empresa, inclusive com entrada de capital estrangeiro (FERRAZ; OLIVEIRA; ASSUMPÇÃO, 2019).

A entrada de capital externo nos grupos sucroalcooleiros fortaleceu a participação do Brasil no mercado mundial. Por meio de suas organizações de cooperação e defesa de interesses do setor, ${ }^{6}$ o país passa a atuar politicamente na ampliação do mercado mundial (FERRAZ; OLIVEIRA; ASSUMPÇÃO, 2019). A título de exemplo, Bruno, Azevedo e Massuquetti (2014) destacam a campanha do Brasil na Organização Mundial do Comércio (OMC), em 2002, contra as políticas protecionistas dos países europeus produtores de açúcar, que resultaram, no ano de 2005, na suspensão pela OMC dos subsídios aos produtores na Europa. Este fato permitiu a abertura à importação pela comunidade europeia do açúcar de outros países exportadores, como o Brasil, a Tailândia e a Austrália.

Nesse contexto o Paraná, aderindo ao novo paradigma tecnológico - não de forma homogênea, pois diversas empresas menos preparadas em termos de capacidade tecnológica encerraram suas atividades e/ou foram incorporadas por outras mais dinâmicas - evoluiu de uma condição periférica na cadeia produtiva sucroalcooleira para se destacar entre os principais produtores do país, já nos primeiros anos do novo século (PAULILLO et al., 2007; RISSARDI JÚNIOR; SHIKIDA, 2007). Em alguns momentos, duran-

\footnotetext{
${ }^{4}$ A criação do Instituto do Açúcar e do Álcool (IAA) em 1933 foi uma reivindicação dos produtores por um órgão "controlador" da economia canavieira, necessário para intermediar conflitos de classe, demandas regionais, etc. Tinha como escopo a defesa das empresas do setor mediante a utilização de uma série de mecanismos de regulação, tais como: controle de preços e da comercialização; estabelecimento de cotas de produção; a garantia de subsídios. Este arranjo institucional proporcionava aos produtores um paradigma subvencionista como modelo de sobrevivência, de tal modo que o produtor não precisava preocupar-se com inovações tecnológicas para minimizar custos de produção e proporcionar um ambiente mais competitivo, pois sua permanência no setor estava garantida através dos expedientes supracitados (SHIKIDA, 2014, p.45-46).

${ }^{5}$ As destilarias paranaenses foram as primeiras a se beneficiarem da extinção das cotas de produção do açúcar, podendo iniciar a produção sem investir na compra da autorização de outra unidade (VIAN; BELIK, 2003).

${ }^{6}$ Com essas mudanças institucionais (extinção do IAA, desregulamentação do setor, arrefecimento do Proálcool), muitas funções previamente exercidas pelo governo passaram a ser de responsabilidade de diversos segmentos envolvidos na cadeia produtiva de cana-de-açúcar (SHIKIDA et al., 2008). Atualmente, a mais representativa instituição de coordenação corporativista do setor é a União da Indústria de Cana-de-açúcar, fundada em 1997, após a desregulamentação do setor e extinção do IAA (UNICA, 2019b).
} 
te essas duas primeiras décadas do século 21, o Estado figurou entre a segunda e terceira posição na produção de cana-de-açúcar no Brasil, com desdobramentos importantes também na geração de empregos (RISSARDI JÚNIOR; SHIKIDA, 2007; FERNANDES; SHIKIDA; CUNHA, 2013).

Analisando os atributos responsáveis pela manutenção do setor canavieiro paranaense no novo paradigma tecnológico, Rissardi Júnior e Shikida (2007) demonstram como os avanços tecnológicos nas diversas áreas (agrícola, administrativa e industrial) foram determinantes para a evolução das empresas no Estado. No setor agrícola os autores destacam com maior percentual de inovação a pesquisa em variedades mais produtivas e a colheita mecanizada; nos setores administrativos, os softwares de gestão e controle; e; na área industrial, a automação . Sumariando a análise, concluem que a área mais impactante para a agroindústria canavieira do Paraná, relativamente aos avanços tecnológicos, foi a agrícola, uma vez que "o principal insumo dessa cadeia produtiva, a cana-de-açúcar, é de origem agrícola" (RISSARDI JÚNIOR; SHIKIDA, 2007, p. 468). Esses apontamentos são de grande relevância para a análise proposta neste trabalho, posto que este paradigma tecnológico é, em sua essência, poupador de mão de obra e, portanto, já nos revela as consequências em termos de evolução do mercado de trabalho, principalmente no que se refere às atividades agrícolas.

No que respeita especificamente ao processo de mecanização (que atualmente atinge praticamente $85 \%$ dos canaviais no Paraná e $95 \%$ na região Centro-Sul), segundo dados do levantamento da Safra 2018/2019 (CONAB, 2018) - cumpre ressaltar que diversos fatores já nos primeiros anos da década de 2000 tornaram o processo de mecanização irreversível, principalmente nos Estados da Região Centro-Sul do país: o ambiente de maior competitividade; a necessidade de investimentos em tecnologias para redução de custos e maior produtividade e a possibilidade de aproveitamento de resíduos da cana crua para a cogeração de energia, somados ao recrudescimento das pressões ambientais pelo fim da queima da palha da cana-de-açúcar, por conta dos efeitos deletérios que essa prática tem sobre o meio ambiente e à saúde das pessoas, fizeram com que as usinas e os produtores passassem a investir na mecanização (MORAES, 2007; ALVES, 2009). Importante frisar que, para além dos requerimentos econômicos e de competitividade, como destaca Moraes (2007), a mecanização se deu também como forma de adequação aos padrões internacionais de sustentabilidade ambiental e social. ${ }^{7}$

Assim, regulamentações no sentido de eliminar a queima controlada como forma de despalha da cana-de-açúcar, contribuíram decisivamente, ao longo dos últimos anos, para a aceleração do processo de mecanização em todo o país. No Paraná, a Resolução Sema n. 76, de 20 de dezembro de 2010, prevê metas de redução gradativa da queima, com a eliminação total devendo ocorrer até 2025 em áreas mecanizáveis, e até 2030 em áreas não mecanizáveis, porém o processo de mecanização está bastante adiantado.

\footnotetext{
A autora destaca os questionamentos colocados pelos concorrentes do Brasil no âmbito da Organização Mundial do Comércio (OMC) que, diante das indagações do Brasil, nos primeiros anos da década de 2000, sobre as políticas comerciais protecionistas adotadas pela União Europeia e Estados Unidos no mercado mundial do açúcar, passaram a argumentar que a competitividade brasileira advinha do não cumprimento de normas ambientais e trabalhistas. A abertura do país ao mercado mundial fez recrudescer as normas institucionais tanto de cunho ambiental quanto de cumprimento da legislação trabalhista. Ver mais em Moraes (2007).
} 
Do ponto de vista social, a mecanização é vista como forma de contornar as condições degradantes do trabalho dos cortadores de cana (PAIXÃO, 2000; VIAN; MORAES; GONÇALVES, 2006; ALVES, 2009).

O avanço do processo de mecanização da lavoura, principalmente na etapa da colheita da cana-de-açúcar, contudo, se constitui em determinante principal da redução da demanda de mão de obra e de uma nova configuração em termos de qualificação e perfil do trabalhador no setor sucroalcooleiro. A problemática principal no que diz respeito ao tema é o impasse entre os aspectos positivos e negativos da mecanização. Em relação às vantagens, destaca-se a melhoria das condições de trabalho, a exigência de melhor qualificação, com repercussões positivas na remuneração, bem como o aumento expressivo do índice de formalização e todos os importantes desdobramentos que esta traz para a vida do trabalhador. Já no que se refere aos aspectos negativos, estes conduzem inequivocamente para a redução da necessidade de mão de obra dos trabaIhadores temporários e menos qualificados, o que remonta a uma importante questão social para o contexto da agroindústria canavieira, que excluirá, definitivamente, uma ampla gama de trabalhadores sem qualificações para se inserirem no novo contexto do trabalho (MORAES, 2007, ALVES, 2009; PAIXÃO, 2000; VIAN; MORAES; GONÇALVES, 2006).

O Estado do Paraná, seguindo a trajetória nacional, passou por um período de oscilações nas contratações entre 1995 e 2000, com ampliação na geração de empregos de aproximadamente $150 \%$ até 2008 , acima da média nacional (ESTANISLAU; DEON; SHIKIDA, 2008). Como demonstra Delgado (2012), contudo, já em 2010 o setor apresentava uma retração de aproximadamente 6 mil postos de trabalho, refletindo o início do processo de mecanização no Estado, mesmo que ainda incipiente à época.

Dessa forma, é com o intuito de dar continuidade a estes estudos que este trabaIho tem por objetivo analisar a geração de emprego formal no setor sucroalcooleiro do Estado do Paraná entre os anos de 2000 e 2017, avaliando os impactos da mecanização no mercado de trabalho do setor.

Cabe, ademais, antes de finalizar este percurso histórico, atentar para a conjuntura atual do setor no Paraná, que parece ter sentido com bastante intensidade os efeitos da crise no setor sucroalcooleiro. ${ }^{8}$ Segundo Dossiê Paraná sobre a indústria sucroalcooleira, lançado pelo Portal novaCana.com (2018), uma conjunção de fatores contribuiu para a diminuição da área plantada e da produtividade nos últimos anos. Além das dificuldades financeiras, políticas públicas desvantajosas e flutuações no mercado internacional do açúcar, que afetaram o país como um todo, o setor no Paraná também sofreu com adversidades climáticas, falta de investimentos nos canaviais e os efeitos da mecanização - que segundo o presidente da Associação de Produtores de Açúcar e Álcool

\footnotetext{
${ }^{8}$ Entre as causas da crise no setor nos últimos anos, Shikida (2014) ressalta: (1) a descoberta do pré-sal e a consequente volta do protagonismo dos combustíveis derivados do petróleo no cenário nacional; (2) o controle artificial do preço da gasolina pelo governo, para tentar manter o controle da inflação, tornando o etanol mais vulnerável e menos competitivo diante de seu substituto e (3) a crise internacional de 2008 que, tendo tolhido os créditos para quase todas as atividades produtivas no mundo, tornou escassos também os investimentos na agroindústria canavieira, tornando mais caras a manutenção e a renovação dos canaviais, bem como a produção de açúcar e álcool, obrigando usinas a encerrarem suas atividades.
} 
do Paraná (Alcopar), Miguel Rubens Tranin, em entrevista ao Portal citado - deu-se de forma rápida e pouco estruturada. Para ele, todos estes fatores convergiram para a retração do setor, que perdeu posição em relação aos principais produtores do Brasil.

A próxima seção trará um panorama do setor no Estado em termos de evolução de área plantada e colhida, produtividade, geração de renda e localização das unidades sucroalcooleiras.

\section{PANORAMA ATUAL DO SETOR SUCROALCOOLEIRO PARANAENSE}

No ano de 2010 o Estado do Paraná ocupava a terceira posição entre os principais produtores de cana-de-açúcar, atrás somente de São Paulo e Minas Gerais (DELGADO, 2012). Em 2011 perdeu posição para Goiás e, mais recentemente, em 2016, para Mato Grosso do Sul, ocupando atualmente a quinta posição (Tabela 1), tanto no que se refere à área plantada quanto na produção total de cana-de-açúcar.

Tabela 1 - Área plantada e colhida e quantidade produzida - Brasil e Estados selecionados, 2017

\begin{tabular}{l|r|r|r|r}
\hline \multirow{2}{*}{ Uf } & \multicolumn{2}{c|}{ Área (ha) } & \multicolumn{2}{c}{ Quantidade (t) } \\
\cline { 2 - 5 } & Plantada & \multicolumn{1}{c}{ Colhida } & \multicolumn{1}{c}{ Tonelada } & $\%$ \\
\hline Brasil & 10.229 .881 & 10.184 .340 & 641.066 & 100 \\
\hline São Paulo & 5.686 .134 & 5.685 .946 & 357.142 & 55,7 \\
\hline Goiás & 922.817 & 922.817 & 70.672 & 11,0 \\
\hline Minas Gerais & 906.497 & 906.464 & 64.886 & 10,1 \\
\hline Mato Grosso do Sul & 661.906 & 661.906 & 46.940 & 7,3 \\
\hline Paraná & 643.580 & 614.373 & 37.047 & 5,8 \\
\hline
\end{tabular}

Fonte: Elaborado a partir de dados UNICA (2019a).

Essa perda de posição do Paraná deve-se à forte expansão da cultura nos Estados de Minas Gerais, Goiás e Mato Grosso do Sul desde a década de 2000, com sensível distanciamento, em relação ao Paraná, principalmente dos Estados de Minas Gerais e Goiás. Quanto à produção de açúcar, o Paraná ainda se mantém como o terceiro maior produtor nacional, atrás de São Paulo e Minas Gerais, e na produção de etanol ocupa a quinta posição. Seguindo a tendência nacional, contudo, para a safra 2018/2019 o Estado está retraindo a produção do açúcar e expandindo a de etanol. Para o açúcar a retração é de aproximadamente $25 \%$ ante uma variação negativa nacional de aproximadamente $16 \%$. Já a expansão do etanol, estima-se, será de aproximadamente $18 \%$ superior à safra passada, ante uma expansão nacional de $23 \%$ aproximadamente (CONAB, 2018). Tais alterações devem-se à queda do preço do açúcar no mercado internacional e a uma situação mais favorável para o etanol no mercado interno ante a alta do dólar e do preço do petróleo.

Entre 2000 e 2017 a área plantada de cana no Paraná aumentou de um total de 327,2 mil hectares para 643,6 mil hectares, com uma expansão aproximada de $97 \%$ (Figura 1). Estimativas da Conab (2018), contudo, para a safra de 2018/2019, apontam para uma leve retração na área plantada, reflexo das dificuldades que o setor tem enfrentado nos últimos anos e também como estratégia das unidades de produção para se tornarem mais eficientes, visto que as áreas não adequadas à colheita mecanizada tendem a deixar de ser cultivadas. A diminuição da área plantada deve-se também à forte 
concorrência entre o setor canavieiro e as culturas de milho e soja no Estado, ambas se revelando mais rentáveis do que a cana-de-açúcar, por conta do alto valor agregado (indústria de carnes) e dos preços mais elevados (Portal novaCana.com, 2018).

Figura 1 - Área plantada com cana-de-açúcar no Paraná, 2000-2017

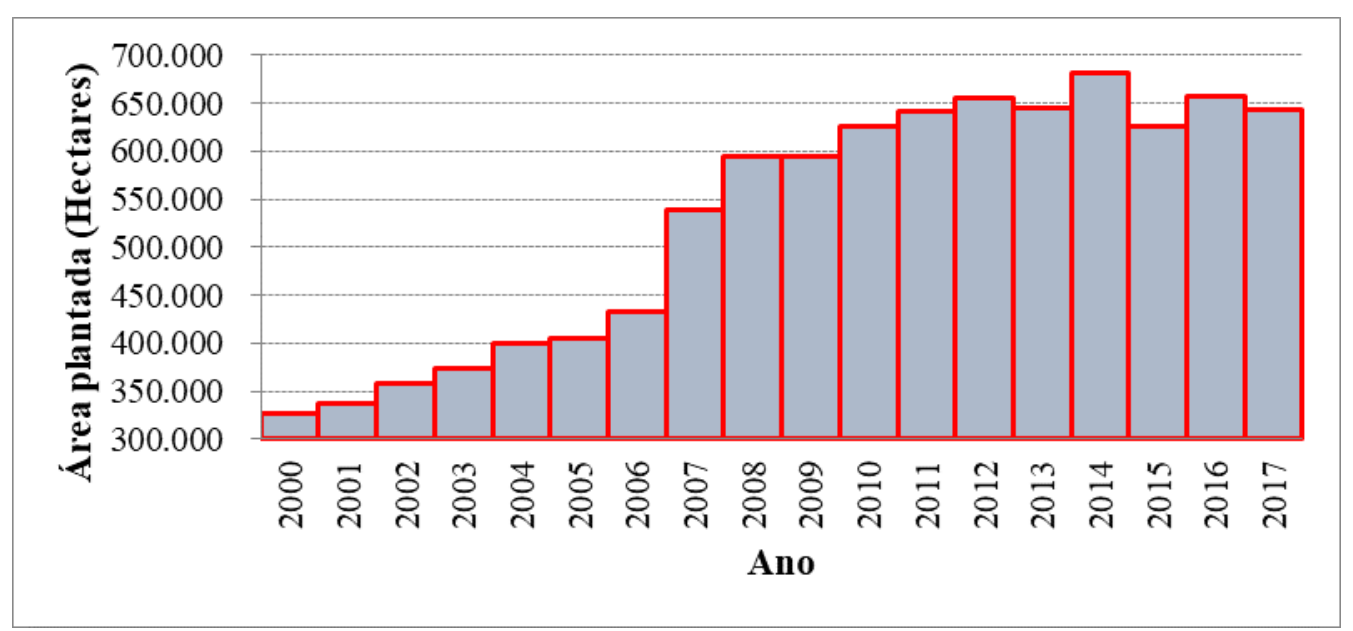

Fonte: Elaborado a partir de dados da UNICA (2019a).

Em relação à evolução da produção da cana-de-açúcar em toneladas, observa-se que o pico da produção foi na safra de 2009/2010, quando a produção atingiu 45.579 mil toneladas, representando um aumento expressivo (136\%) em relação ao ano de 2000 , quando a produção foi de 19.321 toneladas. Não obstante, no referido ano a área plantada ainda não tinha atingido seu pico máximo, ocupando 595.371 mil hectares, o que demonstra que a quantidade registrada naquele ano, superior a outros anos em que se registra uma maior área cultivada, deu-se em virtude do aumento do índice de produtividade (quantidade produzida por hectare), que pode também ser influenciada por condições climáticas favoráveis, condições de manutenção dos canaviais, entre outros aspectos (CONAB, 2018).

Embora o cultivo da cana-de-açúcar seja registrado em todas as regiões do Estado, o cultivo para fins industriais está concentrado em aproximadamente 98 municípios - 45 deles com áreas entre 5 e 25 mil hectares, responsáveis por 75\% do cultivo, e outros 53 com áreas entre 1 e 5 mil hectares, responsáveis por 23\% do cultivo (IBGE, 2017). Estes municípios, que representam aproximadamente $98 \%$ da área cultivada de cana-de-açúcar, estão todos localizados nas regiões Noroeste e Norte do Paraná. As demais regiões, pela sua própria vocação, dedicam-se a outros tipos de cultivo de lavouras temporárias, especificamente grãos, observando-se que as culturas de cana-de-açúcar, nessas regiões, são mais voltadas para a produção de aguardente, açúcar mascavo artesanal, rapadura e também para alimentação animal, como é o caso das regiões Oeste e Sudoeste (SHIKIDA; STADUTO, 2005; DELGADO, 2012). Atualmente, o Estado possui 15 empresas, responsáveis por 30 unidades industriais distribuídas por 29 municípios. Destas 30 unidades, porém, apenas 23 estão plenamente ativas ${ }^{9}$ (Portal novaCana.com, 2018). Essa retração na indústria é resultado do momento de crise setorial, como já mencionado na seção anterior.

\footnotetext{
${ }^{9}$ Duas unidades da Usina Santa Terezinha estão com as atividades paralisadas por falta de cana-de-açúcar, duas usinas da Sabarálcool perderam autorização para produção de etanol e as unidades do Grupo Renuka Vale do Ivaí estão em processo de recuperação judicial.
} 
Segundo a Pesquisa Industrial Anual (PIA) do IBGE (2016) o setor sucroalcooleiro paranaense apresentou um valor de receita líquida de vendas de aproximadamente $\mathrm{R} \$$ 7,3 bilhões de reais, representando 6,24\% da receita nacional do setor (Tabela 2). Outro dado importante disponibilizado pela PIA é o valor da Transformação industrial (VTI), que se refere à renda gerada pelo setor e que em 2016 ficou em 3,4 bilhões de reais, 0 que representa $6,25 \%$ da renda total gerada pelo setor no Brasil.

Tabela 2 - Receitas líquidas de vendas e valor de transformação industrial de empesas industriais com cinco ou mais ocupados - Brasil e Paraná, 2016 (Em mil reais)

\begin{tabular}{ll|rr}
\hline \multicolumn{1}{c|}{ Local } & \multicolumn{1}{c|}{ Atividade } & Receitas de Vendas & \multicolumn{1}{c}{ VTI } \\
\hline Brasil & Indústria & 2.632 .562 .551 & 1.094 .612 .161 \\
& Açúcar e álcool (1) & 116.551 .195 & 54.417 .115 \\
\multirow{2}{*}{ Paraná } & Indústria & & \\
& Açúcar e álcool & 7.276 .380 & 79.503 .581 \\
& & & 3.400 .487 \\
PR/BR (\%) & Indústria & 8,20 & 7,26 \\
& Açúcar e álcool & 6,24 & 6,25 \\
\hline
\end{tabular}

(1) Os valores das Receitas de Vendas e do VTI extraídos da PIA referem-se à soma de dois grupos da Classificação Nacional de Atividades Econômicas (Cnae): o grupo 10.7 (fabricação e refino de açúcar) e 19.3 (fabricação de biocombustíveis).

Fonte: Elaborado a partir de dados do IBGE (2016).

Ademais, a renda gerada pelo setor sucroalcooleiro ( $R \$ 3,4$ bilhões) correspondeu, em 2016, a 4,27\% da renda total da indústria no Estado. Este percentual de participação industrial, como já alertou Delgado (2012), deixa clara a importância do setor, que apresenta números próximos de outros importantes segmentos no Estado, como a indústria de madeira (4\%), indústria de móveis $(2,6 \%)$ e a indústria de automóveis e utilitários (7,10\%). Em comparação com a indústria de carnes, no entanto, que no ano de 2009 tinha uma participação de 4,06\%, ante 3,33\% do setor sucroalcooleiro, percebe-se um sensível distanciamento: o setor de carnes registrou uma participação de 9,15\% ante $4,27 \%$ do setor sucroalcooleiro em 2016. Tal dado corrobora as discussões sobre a concorrência do setor sucroalcooleiro com o setor de grãos no Paraná, em especial as culturas de milho e soja, que estão vinculadas à produção de carne, demonstrando forte crescimento relativamente à cultura canavieira.

A próxima seção traz a análise dos dados referentes à evolução do mercado de trabalho formal no setor ao longo das duas últimas décadas, atentando para a geração de empregos, as mudanças no perfil do trabalhador, bem como a dinâmica salarial.

\section{EVOLUÇÃO DO MERCADO DE TRABALHO FORMAL E PERFIL DOS TRABALHADORES}

Os dados sobre a evolução do número de empregos gerados pelo setor no período de 2000 a 2017 são apresentados considerando-se duas classes de trabalhadores: (1) os envolvidos com as atividades propriamente agrícolas - cultivo e colheita da cana-de-açúcar; e (2) os trabalhadores vinculados às atividades da indústria e outras atividades administrativas. A opção por essa forma de análise deve-se à intenção de destacar 
a evolução da geração de empregos nas atividades agrícolas, que tem sido apontada como a que mais tem perdido postos de trabalho ao longo do tempo, dado o processo de mecanização.

Para tanto, foram utilizadas as bases de dados da Rais e do Caged, que fornecem, respectivamente, o estoque de emprego formal ao término de cada ano e a movimentação mensal das admissões e demissões. Setorialmente, foram consideradas as atividades de cultivo da cana, produção de açúcar e álcool. Tais atividades correspondem a quatro classes de Classificação Nacional de Atividades (códigos 1130, 10716, 10724 e 19314). Depois de extrair os dados referentes a cada uma dessas atividades, fez-se a classificação dos trabalhadores segundo as funções que exercem na empresa, com base nas categorias da Classificação Brasileira de Ocupações (CBO), destacando-se os trabalhadores efetivamente envolvidos com atividades agrícolas (grupo 06 da CBO) dos demais trabalhadores que exercem atividades típicas da indústria e/ou administrativas.

A Figura 2 traz a evolução do número de trabalhadores formais vinculados ao setor sucroalcooleiro dentro do período analisado, destacando-se os trabalhadores envolvidos com as atividades propriamente agrícola dos demais.

Figura 2 - Evolução dos empregos formais nas atividades agrícolas e Outras ocupações no setor sucroalcooleiro paranaense

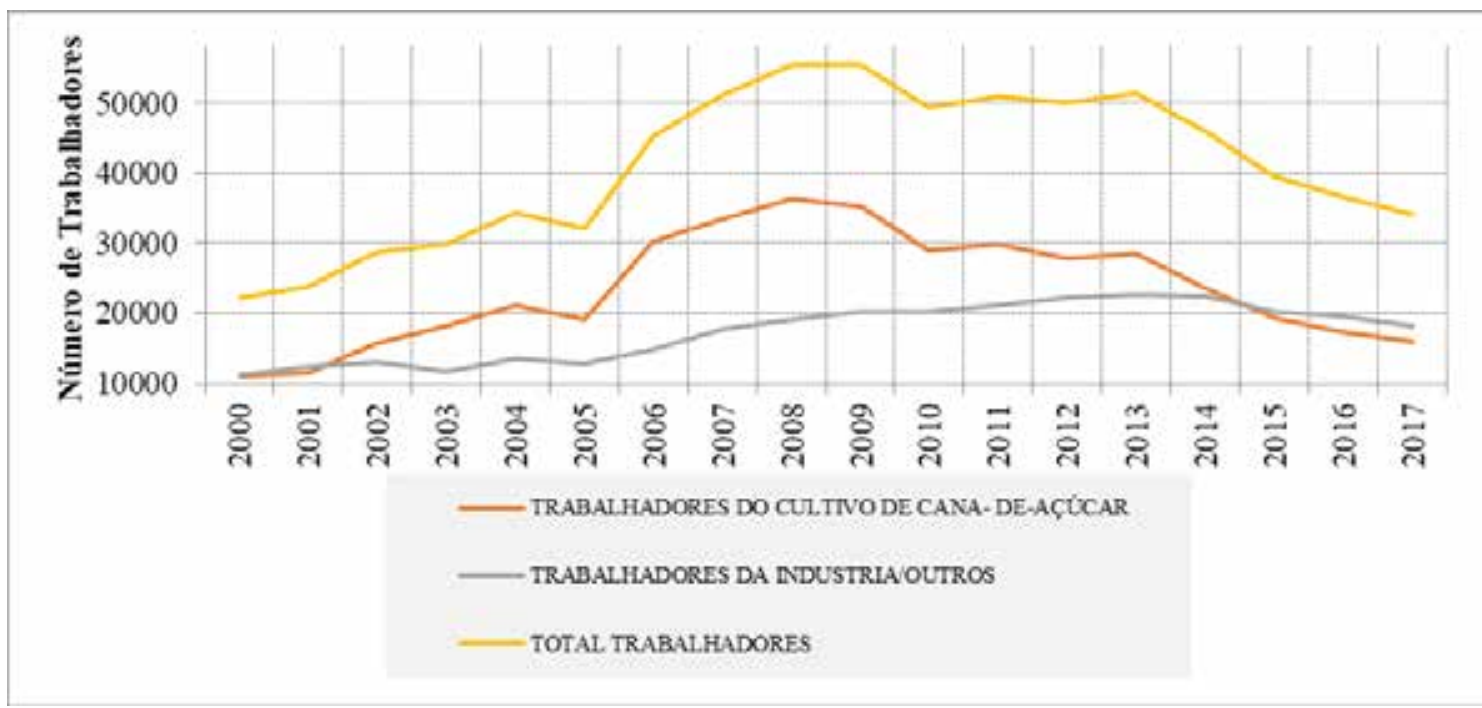

Fonte: Elaborado a partir de dados do MTE/RAIS (2019).

Acompanhando a tendência de crescimento do setor e a evolução dos empregos em âmbito nacional, o período de 2000 a 2009 foi o que registrou a maior evolução no número de trabalhadores empregados no setor sucroalcooleiro paranaense. Com queda já um pouco acentuada no ano de 2010, o setor manteve-se praticamente estável até $o$ ano de 2013, quando novamente voltou a apresentar um acentuado declínio que segue até o último ano de análise. Outro aspecto que pode ser visualizado na Figura 2 é que as atividades agrícolas são responsáveis pelas principais variações na geração de empregos.

Entre 2002 e 2009 o setor registrou uma ampliação de 33,2 mil postos de trabalho (Tabela 3), um crescimento de aproximadamente $150 \%$ relativamente ao ano de 2000. Enquanto, porém, os empregos na indústria cresceram $80 \%$, os agrícolas cresceram aproximadamente $220 \%$. Da mesma forma, foram as atividades agrícolas que apre- 
sentaram o maior declínio no período de 2009 a 2017, registrando uma redução de 19,3 mil postos de trabalho, de um total de 21,3 mil, o que equivale a uma redução de $54,8 \%$ relativamente ao ano de 2009, quando o setor empregou, apenas nesta atividade, mais de 35 mil trabalhadores.

Tabela 3 - Estoque e variação do emprego no setor sucroalcooleiro por tipo de ocupação - Paraná- 2000/2017

\begin{tabular}{l|c|c|c|c|c}
\hline \multicolumn{1}{c|}{ Ocupações } & \multirow{2}{*}{$\mathbf{2 0 0 0}$} & $\mathbf{2 0 0 9}$ & \multirow{2}{*}{$\mathbf{2 0 1 7}$} & \multicolumn{3}{c}{ Variação } \\
\cline { 5 - 6 } & & & & $\mathbf{2 0 0 0 / 2 0 0 9}$ & $\mathbf{2 0 0 9 / 2 0 1 7}$ \\
\hline Trabalhadores em atividades agrícolas & 10.995 & 35.250 & 15.900 & 24.255 & -19.350 \\
Trabalhadores da indústria/outros & 11.218 & 20.167 & 18.159 & 8.949 & -2.008 \\
Total do setor & 22.213 & 55.417 & 34.059 & 33.204 & -21.358 \\
\hline
\end{tabular}

Fonte: Elaborado a partir de dados do MTE/RAIZ (2019).

É notória a diminuição da necessidade de mão de obra nas atividades primárias da cana-de-açúcar, o que nos remete aos efeitos da mecanização, que avançou gradativamente ao longo da última década. É importante ressaltar que em 2010, quando se registra o primeiro declínio nas atividades agrícolas, na ordem de $20 \%$ à época, a colheita mecanizada de cana-de-açúcar no Paraná já era realizada em aproximadamente $30 \%$ dos canaviais, com desdobramentos já bastante perceptíveis no mercado de trabalho (DELGADO, 2012). Em 2017, segundo levantamento da safra pela Conab (2018), apenas $14 \%$ dos canaviais paranaenses ainda realizavam a colheita manual. Dessa forma, com uma área de plantio de 50 mil hectares a mais que no ano de 2009, o setor registrou, em 2017, uma redução de aproximadamente $54 \%$ no número de trabalhadores agrícolas relativamente àquele ano.

As variações no mercado de trabalho podem ser observadas também por meio das informações da movimentação mensal de mão de obra, fornecidas pelo Cadastro Geral de Empregados e Desempregados (Caged). ${ }^{10}$ Se comparados os estoques de pessoal no período da colheita, mais intensivo em mão de obra agrícola, é possível observar a diferença das contratações temporárias ao longo dos anos e o efeito do processo de mecanização nesse tipo de contratação.

Considerando que no Paraná o pico da colheita se dá entre os meses de abril e novembro, conforme dados disponíveis na Secretaria de Agricultura e Abastecimento do Paraná (SEAB, 2019), é possível comparar (Figura 3) como a curva do estoque de trabalhadores alocados em atividades agrícolas foi diminuindo ao longo dos anos 2007, 2009, 2011, 2015 e 2017.

\footnotetext{
${ }^{10} \mathrm{O}$ estoque fornecido pela Rais refere-se ao número de trabalhadores registrados no último dia do ano (31/12). o Caged permite a atualização mensal do estoque, ou seja, todos os admitidos e desligados em dado período de tempo.
} 
Figura 3 - Estoque mensal de emprego formal no setor sucroalcooleiro paranaense.

Anos: 2007, 2009, 2011, 2015, 2017

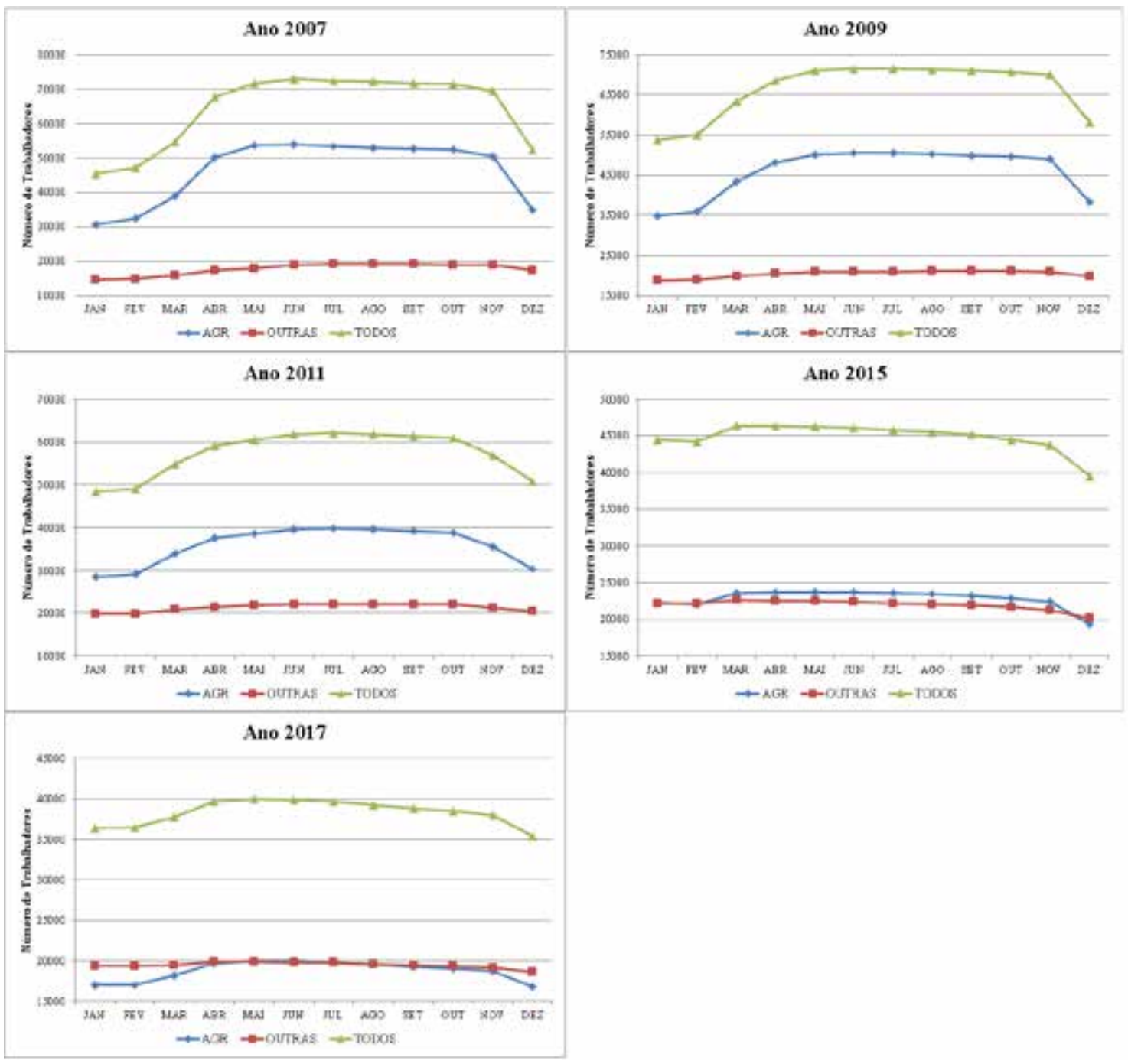

Fonte: Elaborado a partir de dados MTE/CAGED (2019).

Dessa forma, ao analisar as movimentações mensais de admitidos e desligados ao longo dos anos no Caged, é possível observar que a redução total na demanda de mão de obra no setor sucroalcooleiro paranaense (considerando os trabalhadores efetivos e temporários) é bem maior do que os dados da Rais permitem evidenciar. Isso porque como o período da colheita se dá, principalmente, entre os meses de abril e novembro, os meses de dezembro registram um percentual bastante expressivo de demissões, fazendo com que um determinado número de trabalhadores não sejam captados pelas estatísticas da Rais.

Isso posto, avaliando a evolução da curva de trabalhadores alocados em atividades agrícolas, observa-se um constante declínio da contratação desses trabalhadores para os anos retratados. No ano de 2007, com o estoque de aproximadamente 30 mil trabalhadores no mês de janeiro, o setor registrou, no pico da safra (mês de junho), um estoque de aproximadamente 53 mil trabalhadores, com variação aproximada de $75 \%$. Em 2009 e 2011, com uma variação já um pouco menos acentuada nos meses de pico, registram-se acréscimos de aproximadamente 45\% e 39\%, respectivamente. Já em 2015 
a curva referente às atividades agrícolas é praticamente inexistente, com variação positiva nos picos da colheita de apenas $6 \%$, e com declínio constante no estoque total de trabalhadores. Em 2017 a curva das atividades agrícolas apresenta uma leve tendência de crescimento, em comparação com 2015, porém com a mesma tendência de redução no estoque total de trabalhadores registrada em 2015.

Esses dados corroboram as afirmações de Vian, Moraes e Gonçalves (2006), de que a mecanização diminui a necessidade de pessoal adicional no período de safra, proporcionando às usinas certa estabilidade no nível de contratação da mão de obra ao longo do ano. Os trabalhadores com contrato permanente, por sua vez, não possuem mais uma atribuição específica, como os contratados temporariamente, absorvendo diversas atividades necessárias ao cultivo e corte da cana. Essa nova configuração do trabalho, entretanto, se por um lado amplia as possibilidades de contratação permanente daqueles mais qualificados (tratoristas, motoristas, mecânicos, condutores de colheitadeira, técnicos em eletrônica, entre outros) exclui, definitivamente, uma ampla gama de trabalhadores sem qualificações para assumir outras atividades (VIAN; MORAES; GONÇALVES, 2006; MORAES, 2007).

Frisa-se que a redução dos trabalhos sazonais na lavoura da cana não é algo isolado, mas resultado de um processo de modernização no setor agropecuário como um todo, com repercussões no modo de produção de diversas culturas tradicionais brasileiras. Esse novo ciclo de produção reduz a importância dos trabalhadores temporários e impõe uma nova configuração na composição da mão de obra, permanente e mais qualificada, apta a participar de um novo ciclo tecnológico no setor rural (STADUTO; SHIKIDA; BACHA, 2004).

Para a análise do perfil dos trabalhadores foram considerados três anos de referência $(2000,2009$ e 2017) períodos entre os quais aconteceram as maiores variações no mercado de trabalho do setor. A Tabela 4 traz a análise do perfil dos trabalhadores considerando os atributos sexo, faixa etária e escolaridade, segundo o tipo de ocupação.

Tabela 4 - Perfil dos trabalhadores por ocupação - sexo, faixa etária e escolaridade 2000, 2009 e 2017

\begin{tabular}{|c|c|c|c|c|c|c|c|c|c|}
\hline \multirow[b]{2}{*}{ Atributos } & \multicolumn{3}{|c|}{ Ano 2000} & \multicolumn{3}{|c|}{ Ano 2009} & \multicolumn{3}{|c|}{ Ano 2017} \\
\hline & $\begin{array}{c}\text { Ativ. } \\
\text { Agrícolas }\end{array}$ & Outras & Total & $\begin{array}{c}\text { Ativ. } \\
\text { Agrícolas }\end{array}$ & Outras & Total & $\begin{array}{c}\text { Ativ. } \\
\text { Agrícolas }\end{array}$ & Outras & Total \\
\hline $\begin{array}{c}\text { Total } \\
\text { Trabalhadores }\end{array}$ & 10.995 & 11.218 & 22.213 & 35.250 & 20.167 & 55.417 & 15.900 & 18.159 & 34.059 \\
\hline \multicolumn{10}{|l|}{ Sexo ( \%) } \\
\hline Masculino & $84,50 \%$ & $90,60 \%$ & $87,60 \%$ & $74,84 \%$ & $89,15 \%$ & $80,05 \%$ & $80,47 \%$ & $87,92 \%$ & $84,18 \%$ \\
\hline Feminino & $15,50 \%$ & $9,40 \%$ & $12,43 \%$ & $25,16 \%$ & $10,85 \%$ & $19,95 \%$ & $19,53 \%$ & $12,57 \%$ & $15,82 \%$ \\
\hline \multicolumn{10}{|l|}{ Faixa etária } \\
\hline de 15 a 17 anos & $0,55 \%$ & $0,38 \%$ & $0,46 \%$ & $0,01 \%$ & $0,31 \%$ & $0,12 \%$ & ( 1 Trab. ) & $0,40 \%$ & $0,22 \%$ \\
\hline de 18 a 24 anos & $21,30 \%$ & $21,09 \%$ & $21,19 \%$ & $14,94 \%$ & $20,13 \%$ & $16,83 \%$ & $11,81 \%$ & $13,06 \%$ & $12,48 \%$ \\
\hline de 25 a 39 anos & $49,30 \%$ & $50,29 \%$ & $49,80 \%$ & $44,19 \%$ & $46,34 \%$ & $44,97 \%$ & $34,77 \%$ & $44,12 \%$ & $39,75 \%$ \\
\hline de 40 a 49 anos & $17,03 \%$ & $18,27 \%$ & $17,66 \%$ & $25,91 \%$ & $21,19 \%$ & $24,19 \%$ & $26,67 \%$ & $24,02 \%$ & $25,26 \%$ \\
\hline$>=50$ anos & $11,80 \%$ & $9,93 \%$ & $10,85 \%$ & $14,95 \%$ & $12,03 \%$ & $13,89 \%$ & $26,74 \%$ & $18,41 \%$ & $22,30 \%$ \\
\hline \multicolumn{10}{|l|}{ Escolaridade ${ }^{(1)}$} \\
\hline Analfabeto & & & $3,11 \%$ & & & $2,09 \%$ & & & $0,83 \%$ \\
\hline 1 a 5 anos & & & $45,67 \%$ & & & $41,33 \%$ & & & $20,75 \%$ \\
\hline
\end{tabular}




\begin{tabular}{lccc}
6 a 9 anos & $26,04 \%$ & $26,46 \%$ & $26,21 \%$ \\
10 a 13 anos & $14,81 \%$ & $26,98 \%$ & $45,87 \%$ \\
Mais de 13 anos & $10,38 \%$ & $3,14 \%$ & $6,34 \%$ \\
\hline
\end{tabular}

Para o atributo escolaridade, a Rais não disponibiliza a estratificação dos trabalhadores segundo funções que ocupam pela CBO no ano de 2009 e 2017, por isso optou-se por não incluir também a estratificação referente ao ano de 2000.

Fonte: Elaborado a partir de dados do MTE/RAIS (2019).

A participação feminina no setor sofreu pequenas variações nos três anos analisados, apresentando, em 2017, um aumento percentual de 2,5\% na composição total, relativamente ao primeiro ano de análise. A tendência de maior participação no desempenho das atividades agrícolas manteve-se ao longo dos três períodos. Em 2017 as mulheres representaram $19,5 \%$ da força de trabalho nas atividades agrícolas e $12,5 \%$ nas demais ocupações no setor, com participação total de $15,82 \%$ ante $12,43 \%$ no ano de 2000.

Observa-se uma mudança no perfil do trabalhador relativamente à faixa etária. Enquanto no primeiro ano de análise aproximadamente $71 \%$ da força de trabalho era composta por trabalhadores com até 39 anos de idade, nos anos 2009 e 2017 a proporção destes trabalhadores diminuiu para $62 \%$ e 52\%, respectivamente. Essa redução percentual aconteceu de maneira bastante equilibrada entre as duas principais faixas etárias que compõem o estrato (uma vez que o percentual de trabalhadores menores, entre 15 e 17 anos, é incipiente), reduzindo-se a proporção tanto de trabalhadores entre 18 a 24 anos quanto os de 25 a 39 anos. Ao mesmo tempo, houve um acréscimo de aproximadamente $8 \%$ de trabalhadores com faixa etária entre 40 e 49 anos e de $12 \%$ dos trabalhadores com mais de 50 anos.

Nestes dois últimos estratos registrou-se, no ano de 2017, uma maior participação nas atividades agrícolas, ou seja, 53,4\% do total da mão de obra empregada nesta atividade tinha idade superior a 40 anos de idade, enquanto $57,6 \%$ da mão de obra empregada nas demais atividades do setor era composta por trabalhadores mais jovens, entre 18 e 39 anos. Tais mudanças na composição da faixa etária podem estar relacionadas ao processo de transição demográfica pelo qual o Brasil está passando, com o crescimento da população economicamente ativa (entre 15 e 59 anos) e consequente envelhecimento populacional nos próximos anos ${ }^{11}$ (IBGE, 2018).

Outra importante mudança no perfil dos trabalhadores está no nível de escolaridade. Se no ano de 2000 quase a metade dos trabalhadores do setor tinham no máximo até 5 anos de estudos, em 2017 esses representavam menos de 22\%. Observa-se, no entanto, que esta mudança ocorreu principalmente depois de 2009, ano em que ainda se registrou um alto percentual com baixa escolaridade. Assim, enquanto a participação percentual do estrato de trabalhadores na faixa entre 6 a 9 anos de escolaridade permaneceu praticamente inalterada ao longo dos três períodos analisados, houve um acentuado aumento na proporção daqueles com escolaridade entre 10 e 13 anos - totalizando $45,8 \%$ do setor. Uma leve retração, porém, pode ser constatada em relação

\footnotetext{
${ }^{11}$ Segundo as projeções populacionais 2018 elaboradas pelo IBGE, em 2060 o percentual da população com 65 anos ou mais de idade chegará a 25,5\% (58,2 milhões de idosos), enquanto em 2018 essa proporção é de 9,2\% (19,2 milhões). Já os jovens ( 0 a 14 anos) deverão representar 14,7\% da população (33,6 milhões) em 2060, frente a $21,9 \%$ (44,5 milhões).
} 
aos trabalhadores com mais de 13 anos de estudos - de aproximadamente $10 \%$ em 2000 para $6 \%$ em 2017. Constatou-se, de toda a forma, uma sensível melhora nos níveis de escolaridade no setor, com 52,2\% dos trabalhadores apresentando níveis de escolaridade acima dos 10 anos de estudos. Estes dados são bastante diferentes dos registrados no ano de 2000 , quando praticamente esse mesmo percentual de trabalhadores ( $49 \%$ à época) tinha no máximo até 5 anos de estudos.

Essa alteração no nível de escolaridade dos trabalhadores do setor é mais um indicativo do novo perfil do trabalhador requerido pelo setor sucroalcooleiro num momento de consolidação de um novo ciclo tecnológico, que reconfigura as formas de produção e o perfil da mão de obra ocupada (SHIKIDA; AZEVEDO; VIAN, 2011).

A Tabela 5 traz a composição do setor por faixas salariais nos anos 2000, 2009 e 2017. No ano de 2017, 79,3\% dos trabalhadores do setor receberam até no máximo 3 salários mínimos. Esse percentual é menor que em 2009 (89,1\%) e um pouco maior do que em 2000 (77,2\%). Uma alteração importante pode ser observada na distribuição dos trabalhadores por faixas salariais, havendo, neste último ano, uma significativa redução do percentual de trabalhadores que receberam até 1,5 salário mínimo - 16,4\% ante $33,5 \%$ em 2009 e $25 \%$ em 2000.

Tabela 5 - Distribuição do setor por faixas salariais nos anos 2000, 2009 e 2017

\begin{tabular}{|c|c|c|}
\hline Ano & Faixa Salarial (em salários mínimos) & Número de Trabalhadores (\%) \\
\hline \multirow{6}{*}{2000} & até 1,5 salário & 25,0 \\
\hline & $1,51-2$ & 26,9 \\
\hline & $2,01-3$ & 25,3 \\
\hline & $3,01-4$ & 12,7 \\
\hline & Acima de 4 salários & 9,5 \\
\hline & Não Classificados & 0,6 \\
\hline \multirow{6}{*}{2009} & até 1,5 salário & 33,5 \\
\hline & $1,51-2$ & 29,9 \\
\hline & $2,01-3$ & 25,9 \\
\hline & $3,01-4$ & 4,9 \\
\hline & Acima de 4 salários & 3,7 \\
\hline & Não Classificados & 2,1 \\
\hline \multirow{6}{*}{2017} & até 1,5 salário & 16,4 \\
\hline & $1,51-2$ & 27,9 \\
\hline & $2,01-3$ & 35,0 \\
\hline & $3,01-4$ & 10,0 \\
\hline & Acima de 4 salários & 6,6 \\
\hline & Não Classificados & 4,1 \\
\hline
\end{tabular}

Fonte: Elaborado a partir de dados do MTE/RAIS (2019).

O percentual de trabalhadores na faixa entre 2 e 3 salários, por sua vez, que era de $25,8 \%$ em 2009 e de $25,3 \%$ em 2000 , subiu para $35 \%$, indicando um razoável deslocamento de trabalhadores para esta faixa salarial mais elevada. 0 percentual de traba- 
Ihadores com rendimentos acima de 3 salários mínimos foi de 16,6\% em 2017, revelando uma acentuada recuperação com relação a 2009, mas ainda abaixo do registrado em 2000, quando este estrato agregava $22,2 \%$ dos trabalhadores.

A distribuição das faixas salariais por tipo de ocupação está disposta na Tabela 6.

Tabela 6 - Faixas salariais por tipo de ocupação no setor - anos: 2000, 2009 e 2017

\begin{tabular}{|c|c|c|c|c|c|}
\hline Ano & Faixa Salarial & $\begin{array}{c}\text { Atividades } \\
\text { Agrícolas }\end{array}$ & $\%$ & $\begin{array}{c}\text { Demais } \\
\text { ocupações }\end{array}$ & $\%$ \\
\hline \multirow{9}{*}{2000} & até 1,5 salário & 4664 & 42,42 & 885 & 7,89 \\
\hline & de 1,51 a 2 salários & 3582 & 32,58 & 2369 & 21,12 \\
\hline & de 2,01 a 3 salários & 1929 & 17,54 & 3708 & 33,05 \\
\hline & de 3,01 a 4 salários & 553 & 5,03 & 2272 & 20,25 \\
\hline & 4,01 a 5 salários & 70 & 0,64 & 836 & 7,45 \\
\hline & 5,01 a 7 salários & 55 & 0,50 & 567 & 5,05 \\
\hline & 7,01 a 10 salários & 21 & 0,19 & 238 & 2,12 \\
\hline & mais de 10 & 14 & 0,13 & 313 & 2,79 \\
\hline & não informado & 107 & 0,97 & 30 & 0,27 \\
\hline \multirow{9}{*}{2009} & até 1,5 salário & 15376 & 43,62 & 3189 & 15,81 \\
\hline & de 1,51 a 2 salários & 11986 & 34,00 & 4579 & 22,71 \\
\hline & de 2,01 a 3 salários & 6195 & 17,57 & 8151 & 40,42 \\
\hline & de 3,01 a 4 salários & 467 & 1,32 & 2233 & 11,07 \\
\hline & 4,01 a 5 salários & 94 & 0,27 & 640 & 3,17 \\
\hline & 5,01 a 7 salários & 106 & 0,30 & 528 & 2,62 \\
\hline & 7,01 a 10 salários & 40 & 0,11 & 296 & 1,47 \\
\hline & mais de 10 & 23 & 0,07 & 349 & 1,73 \\
\hline & não informado & 963 & 2,73 & 202 & 1,00 \\
\hline \multirow{9}{*}{2017} & até 1,5 salário & 3.974 & 24,99 & 1.618 & 8,91 \\
\hline & 1,51 a 2 salários & 5.700 & 35,85 & 3806 & 20,96 \\
\hline & 2,01 a 3 salários & 3.920 & 24,65 & 7999 & 44,05 \\
\hline & 3,01 a 4 salários & 796 & 5,01 & 2600 & 14,32 \\
\hline & 4,01 a 5 salários & 159 & 1,00 & 853 & 4,70 \\
\hline & 5,01 a 7 salários & 96 & 0,60 & 539 & 2,97 \\
\hline & 7,01 a 10 salários & 40 & 0,25 & 272 & 1,50 \\
\hline & mais de 10 & 28 & 0,18 & 263 & 1,45 \\
\hline & não informado & 1187 & 7,47 & 209 & 1,15 \\
\hline
\end{tabular}

Fonte: Elaborado a partir de dados do MTE/RAIS (2019).

As atividades agrícolas são as que concentraram a maior proporção dos trabalhadores com até 2 salários mínimos, embora com significativa redução em 2017 relativamente aos anos anteriores. Nos anos de 2000 e 2009 aproximadamente $75 \%$ dos trabaIhadores agrícolas recebiam até 2 salários mínimos, já em 2017 esse percentual foi de $61 \%$. Dessa forma, nesse último ano tem-se, pela primeira vez, nos três períodos analisados, um aumento percentual dos trabalhadores agrícolas na faixa de 2 a 3 salários mínimos $-24,7 \%$ ante aproximadamente $17,5 \%$ nos períodos anteriores. Assim, se nos demais anos da análise aproximadamente $95 \%$ dos trabalhadores agrícolas receberam no máximo até 3 salários mínimos, no último ano esse percentual caiu para $85,5 \%$, havendo um sutil deslocamento percentual para as faixas subsequentes. 
Dessa forma, em consonância com os dados sobre a distribuição por faixa salarial da Tabela 5, as atividades agrícolas apresentaram uma importante redução no percentual do pessoal com remuneração até 1,5 salários mínimo. Enquanto em 2000 e 2009 o maior percentual de trabalhadores alocados nestas atividades recebia até 1,5 salários mínimo, no ano de 2017 a maioria recebeu entre 1,5 e 2 salários, tendo sido observado razoável aumento na proporção de trabalhadores também na faixa entre 2,1 a 3 salários. Tais alterações na dinâmica salarial das atividades agrícolas são um indicativo das mudanças que se processaram neste mercado que, em decorrência do processo de modernização, passou a demandar ao longo dos anos um pessoal mais qualificado e, consequentemente, um pouco mais bem remunerado.

Para as demais ocupações da indústria sucroalcooleira, a proporção daqueles que receberam até 2 salários é menor do que nas atividades agrícolas. Entre os trabalhadores alocados em atividades próprias da indústria e/ou administrativas, a maior concentração de pessoal está na faixa entre 2 e 3 salários mínimos, dinâmica que se manteve ao longo dos três períodos analisados. Se somados os trabalhadores da faixa entre $3 \mathrm{e}$ 4 salários, tem-se que em 2017 mais da metade (58,4\%) recebeu entre 2 e 4 salários mínimos. Nota-se, também, que nas demais faixas remuneratórias, acima de 4 salários mínimos, embora incipientes em termos de porcentagem, há uma maior concentração destes trabalhadores, relativamente às atividades agrícolas. Dessa forma, sem demonstrar alterações significativas na dinâmica salarial, a indústria manteve os melhores níveis salariais no setor ao longo dos anos.

Concluindo a análise dos resultados sobre o perfil dos trabalhadores no setor sucroalcooleiro paranaense, tem-se na Tabela 7 a composição dos níveis salariais por faixa de escolaridade.

Tabela 7 - Composição das faixas salariais por nível de escolaridade - anos 2000, 2009 e 2017

\begin{tabular}{|c|c|c|c|c|c|c|c|}
\hline Ano & $\begin{array}{c}\text { Escolaridade / } \\
\text { Salário }\end{array}$ & $\begin{array}{c}\text { até } 1,5 \\
\text { salário (\%) }\end{array}$ & $\begin{array}{c}1,51-2 \\
(\%)\end{array}$ & $\begin{array}{c}2,01-3 \\
(\%)\end{array}$ & $\begin{array}{c}3,01-4 \\
(\%)\end{array}$ & $\begin{array}{l}\text { Acima de } 4 \\
\text { salários (\%) }\end{array}$ & $\begin{array}{c}\text { Não } \\
\text { Classificados }\end{array}$ \\
\hline \multirow{5}{*}{2000} & Analfabeto & 6 & 4 & 1,5 & 0,25 & 0,14 & 0,04 \\
\hline & Até 5 anos & 61 & 53 & 43 & 28 & 17 & 0,37 \\
\hline & 6 a 9 anos & 21 & 25 & 30 & 32 & 23 & 0,17 \\
\hline & 10 a 13 anos & 7 & 13 & 17 & 21 & 29 & 0,02 \\
\hline & $\begin{array}{l}\text { mais que } 13 \\
\text { anos }\end{array}$ & 5 & 5 & 8 & 20 & 32 & 0,02 \\
\hline \multirow{5}{*}{2009} & Analfabeto & 3 & 2 & 0,66 & 0,11 & 0 & 0,13 \\
\hline & Até 5 anos & 53 & 45 & 29 & 17 & 6 & 1,44 \\
\hline & 6 a 9 anos & 25 & 26 & 30 & 28 & 12 & 0,40 \\
\hline & 10 a 13 anos & 17 & 25 & 38 & 48 & 41 & 0,13 \\
\hline & $\begin{array}{l}\text { mais que } 13 \\
\text { anos }\end{array}$ & 1 & 1 & 2 & 6 & 41 & 0 \\
\hline
\end{tabular}




\begin{tabular}{l|l|c|c|c|c|c|c}
\hline \multirow{2}{*}{2017} & Analfabeto & 2 & 1 & 0,08 & 0,03 & 0 & 0,22 \\
\cline { 2 - 8 } & Até 5 anos & 35 & 24 & 13 & 9 & 3 & 2,53 \\
\cline { 2 - 8 } & 6 a 9 anos & 27 & 29 & 29 & 20 & 9 & 0,90 \\
\cline { 2 - 8 } & 10 a 13 anos & 34 & 42 & 54 & 62 & 46 & 0,43 \\
\cline { 2 - 8 } & $\begin{array}{l}\text { mais que 13 } \\
\text { anos }\end{array}$ & 2 & 3 & 4 & 9 & 42 & 0,02 \\
\hline
\end{tabular}

Fonte: Elaborado a partir de dados do MTE/RAIS (2019).

Foram observadas significativas alterações ao longo dos três períodos em virtude, provavelmente, da melhora no nível de escolaridade apresentado pelos trabalhadores nos últimos anos. Assim, é perceptível a redução da participação de pessoal menos qualificado, com até 5 anos de estudos nas faixas salariais acima de 2 salários mínimos. Se no ano 2000 as faixas salariais entre 2,1 e 3 salários; 3,1 e 4 salários e acima de 4 salários eram compostas, respectivamente, por $44,5 \%, 28,3 \%$ e $17,1 \%$ por trabalhadores com até no máximo 5 anos de estudos, em 2017 esse percentual foi reduzido para $13 \%, 9 \%$ e $3 \%$, respectivamente. Nestes termos, também aumentou a participação do pessoal mais qualificado (com escolaridade acima de 10 anos de estudos) nas faixas salariais acima de 3 salários mínimos. Em 2017, 71\% dos trabalhadores que compunham a faixa salarial entre 3 e 4 salários mínimos tinham mais de 10 anos de estudos ante $54 \%$ em 2009 e $41 \%$ em 2000. Da mesma forma, o estrato de trabalhadores com mais de 4 salários, que durante os três períodos analisados foi composto, em sua maioria, por trabalhadores com níveis de escolaridade acima dos 10 anos de estudos, também registrou aumento proporcional, com participação de $86 \%$ ante $81 \%$ em 2009 e $61 \%$ em 2000.

\section{CONSIDERAÇÕES FINAIS}

Este artigo analisou a evolução do mercado de trabalho do setor sucroalcooleiro paranaense em termos de geração de empregos e perfil da mão de obra nas duas últimas décadas. Os resultados apontaram para um período de expansão na geração de empregos entre 2000 e 2009, cujo crescimento acompanhou a evolução da área cultivada de cana-de-açúcar. A partir de 2010, entretanto, mesmo ainda com certa expansão da área cultivada, o mercado de trabalho apresentou uma razoável retração, que se intensificou após o ano de 2013 e manteve queda constante até 2017.

As atividades agrícolas foram responsáveis pelas principais variações na dinâmica do mercado de trabalho, registrando um crescimento de aproximadamente $220 \%$ no período de expansão e uma diminuição de $55 \%$ no período de retração. Quanto ao perfil da mão de obra, foram registradas alterações significativas na composição etária do setor, com redução na participação de trabalhadores com até 39 anos de idade e aumento na participação de trabalhadores acima de 50 anos, indicando um envelhecimento da mão de obra empregada. Da mesma forma, os resultados apontaram para uma sensível melhora nos níveis de escolaridade .

A dinâmica salarial também apresentou alterações importantes, registrando ganhos no setor como um todo e, mais nitidamente, nas atividades agrícolas. Houve um significativo deslocamento de trabalhadores entre faixas salariais, com redução percen- 
tual no número de trabalhadores que receberam até 1,5 salário mínimo e aumento dos que receberam entre 2 e 3 salários mínimos. Os melhores níveis salariais, entretanto, estão definitivamente reservados aos mais bem qualificados.

Desse modo, ao longo do período analisado, diversas mudanças se processaram no perfil do trabalhador formal do setor sucroalcooleiro paranaense. De maneira geral, os trabalhadores estão mais velhos, mais bem qualificados e com um rendimento um pouco mais elevado em termos de salários mínimos. Mais significativas, porém, são as alterações que se processaram em termos de geração de empregos, com redução de postos de trabalho na ordem de $40 \%$ na composição total do setor ao longo da última década. Nesta redução, ressalta-se, não estão inclusos aqueles postos de trabalhos temporários. Os dados de 2017 sumarizam a nova dinâmica do setor sucroalcooleiro paranaense: menos intensivo em mão de obra, principalmente agrícola; mais seletivo e um pouco mais bem remunerado comparativamente aos anos anteriores.

Esses apontamentos corroboram alguns estudos, já referenciados neste artigo sobre os efeitos da mecanização, bem como o impacto de todo o processo de modernização agrícola e agroindustrial na redução de postos de trabalho e na mudança de perfil do trabalhador agrícola. Dessa forma, o futuro dos empregos no setor sucroalcooleiro, principalmente no Estado do Paraná, parece depender sobremaneira do crescimento da indústria, de modo que haja um incremento do emprego em outras funções que não sejam as agrícolas. Para além das questões macroeconômicas e outras políticas institucionais que podem vir a afetar o setor, as expectativas, em âmbito nacional, apontam para a Política Nacional de Biocombustíveis (Renovabio), criada no final de 2017, a partir da publicação da Lei $n^{\circ} 13.576$, de 26/12/2017, cujas diretrizes propõem um aumento significativo da produção de etanol no país, com estímulo à produção, aumento da previsibilidade aos produtores e, por conseguinte, a recuperação na dinâmica econômica da atividade..$^{12}$

Ainda no que diz respeito à geração de empregos, é preciso frisar, como já fizeram Vian e Belik (2003), que os empregos na indústria não serão suficientes para empregar todo o contingente de mão de obra liberada, gerando a necessidade de estabelecimento de políticas regionais que visem à absorção de uma parcela dessa mão de obra em outras atividades. A este respeito discute-se sobre o potencial das políticas de incentivo à agricultura familiar; a destinação social daquelas áreas desocupadas pela cana-de-açúcar, em virtude da mecanização completa do corte; bem como a reforma agrária nas áreas de origem dos trabalhadores migrantes, ${ }^{13}$ o que não foi aqui aprofundado por não ser tema de investigação deste trabalho.

\footnotetext{
${ }^{12}$ A Política Nacional de Biocombustível (Renovabio) está em consonância com o processo global de transição energética, em que os biocombustíveis, em especial o etanol, apresentam-se como uma opção consistente para a substituição de combustíveis fósseis em larga escala. Assim, com o objetivo principal de cumprir os compromissos de redução de emissões de gases causadores do efeito estufa, firmados pelo Brasil no Acordo de Paris, o programa apresenta-se também como uma auspiciosa política pública de estímulo ao setor sucroalcooleiro, quando se vale de mecanismos como a certificação de biocombustíveis, a precificação e comercialização de créditos de descarbonização, bem como incentivos fiscais, financeiros e creditícios, que visam a promover maior estabilidade aos preços dos biocombustíveis, constantemente afetados pelas oscilações mundiais no preço do petróleo (GRASSI; PEREIRA, 2019). Nesse sentido, tal política parece definir, depois de longos anos de debate, o papel do álcool na matriz energética do país, uma diretriz de política com potencial de finalmente estabilizar a demanda e promover um crescimento sustentado da produção (VIAN; BELIK, 2003; SHIKIDA, 2014).

${ }^{13}$ Ver mais em Vian e Belik (2003) e Alves (2009).
} 
Sugere-se, por fim, como agenda de trabalho, que mais estudos sejam realizados sobre o tema em outros Estados produtores de cana-de-açúcar, como forma de investigar os mesmos aspectos analisados nesta pesquisa em outros cenários. Ademais, um aprofundamento, por meio de análise qualitativa, sobre as condições de trabalho dos sujeitos pesquisados e outros desdobramentos sobre o impacto social desta redução dos empregos no setor, que não acontece isolada de outros campos de atuação econômica e produtiva, são temas que podem ser incluídos nesta agenda.

\section{REFERÊNCIAS}

ALVES, F. Políticas públicas compensatórias para a mecanização do corte de cana crua: indo direto ao ponto. Revista Ruris, Campinas, v. 3, n. 1, p. 153-178, 2009.

BRUNO, F. R.; AZEVEDO, A. Z.; MASSUQUETTI, A. Os contenciosos comerciais e os principais casos de retaliação do Brasil à prática de subsídios agrícolas na Organização Mundial do Comércio. Revista Ciência Rural, v. 44, n. 1, p. 188-195, 2014.

CEPEA. Centro de Estudos Avançados em Economia Aplicada. Mercado de trabalho do agronegócio: a dinâmica dos empregos formais na agroindústria sucroenergética de 2000 a 2016. Especial Temático, Piracicaba, v. 1, n. 2, 2018.

CONAB. Companhia Nacional de Abastecimento. Acompanhamento de safra brasileira: cana-de-açúcar, v. 5, n. 3, Safra 2018/2019 - Terceiro levantamento, Brasília, p. 1-71, dez. 2018.

DELGADO, P. R. Evolução e perfil do emprego no setor sucroalcooleiro paranaense. Caderno Ipardes. Curitiba, v. 2, n. 1, p. 44-57, 2012.

ESTANISLAU, P.; DEON, L. E.; SHIKIDA, P. F. A. Composição do mercado de trabalho formal da agroindústria canavieira do Estado do Paraná (1995 a 2008). Cadernos de Economia, a. 12, n. 23, p. 125-148, 2008.

FERRAZ, D.; OLIVEIRA, F. C. R.; ASSUMPÇÃO, M. R. P. Análise do impacto de mudanças institucionais sobre a produção de açúcar no Brasil entre 1980 a 2015. Exacta, São Paulo, v. 17, n. 1, p. 127-145, 2019.

FERNANDES, C. B. S.; SHIKIDA, P. F. A.; CUNHA, M. S. O mercado de trabalho formal do setor sucroalcooleiro no Brasil. Redes - Rev. Des. Regional, Santa Cruz do Sul, v. 18, n. 2, p. 177-192, 2013.

GRASSI, M. C. B; PEREIRA, G. A. G. Energy-cane and RenovaBio: Brazilian vectors to boost the development of Biofuels. Industrial Crops \& Products, 129, p. 201-205, 2019.

IBGE. Instituto Brasileiro de Geografia e Estatística. Projeção da População 2018: número de habitantes do país deve parar de crescer em 2047. Disponível em: https://agenciadenoticias.ibge.gov.br/agencia-sala-de-imprensa/2013-agencia-de-noticias/releases/21837-projecao-da-populacao-2018-numero-de-habitantes-do-pais-deve-parar-de-crescer-em-2047. Acesso em: 6 abr. 2019.

IBGE. Instituto Brasileiro de Geografia e Estatística. Pesquisa Industrial Anual - Empresa - PIA Empresa - 2016. Disponível em: https://www.ibge.gov.br/estatisticas-novoportal/economicas/industria/9042-pesquisa-industrial-anual.html?=\&t=resultados. Acesso em: 30 jan. 2019.

IBGE. Instituto Brasileiro de Geografia e Estatística. Produção Agrícola Municipal - PAM - 2017. Disponível em: https://www.ibge.gov.br/estatisticas-novoportal/economicas/agricultura-e-pecuaria/9117-Producao-agricola-municipal-culturas-temporarias-e-permanentes.html?=\&t=resultados. Acesso em: 7 fev. 2019.

MTE; RAIS. Ministério do Trabalho e Emprego; Relação Anual de Informações Sociais. Bases Estatísticas Rais/Caged. Disponível em: http://bi.mte.gov.br/bgcaged/rais.php. Acesso em: 10 jan. 2019.

MORAES, M. A. F. D. O mercado de trabalho da agroindústria canavieira: desafios e oportunidades. Revista de Economia Aplicada, Ribeirão Preto, v. 11, p. 605-619, 2007.

PAIXÃO, M. Relações de trabalho na agroindústria sucroalcooleira do Brasil: exclusão ou cidadania? In: FERRAZ, J.; PRADA, L.; PAIXÃO, M. (org.). Certificação socioambiental do setor sucroalcooleiro. São Paulo: Embrapa; Imaflora; Fase, 2000. p. 111-145.

PARANÁ. Resolução Sema n. 076 de 20 de dezembro de 2010. Dispõe sobre eliminação gradativa de despalha da cana-de-açúcar através da queima controlada e dá outras providências. Disponível em: https:// www.legislacao.pr.gov.br/legislacao/listarAtosAno.do?action=exibir\&codAto=59961\&indice=1\&totalRegistros=87\&anoSpan=2019\&anoSelecionado=2010\&mesSelecionado=0\&isPaginado=true. Acesso em: 20 jan. 2019.

PAULILLO, L. F.; VIAN, C. E. de F.; SHIKIDA, P. F. A.; MELLO, F. T. de. Álcool combustível e biodiesel no Brasil. Quo Vadis? Revista de Economia e Sociologia Rural, Brasília, v. 45, n. 3.p. 531-565, 2007. 
PORTAL novaCana.com. Dossiê Paraná: indústria sucroenergética tem mais potencial que investimentos. 2018. Disponível em: https://www.novacana.com/n/industria/usinas/dossie-parana-industria-sucroenergetica-potencial-investimentos-170918. Acesso em: 2 fev. 2019.

RISSARDI JÚNIOR, D. J.; SHIKIDA, P. F. A. A agroindústria canavieira do Paraná pós-desregulamentação: uma abordagem neoschumpeteriana. RER, Rio de Janeiro, v. 45, n. 2, p. 445-473, 2007.

SEAB. Secretaria de Estado da Agricultura e do Abastecimento do Paraná. Deral - Departamento de Economia Rural: Calendário Agrícola. Evolução de Plantio, colheita e comercialização: cana-de-açúcar. Disponível em: http://www.agricultura.pr.gov.br. Acesso em: 10 fev. 2019.

SHIKIDA, P. F. A.; BACHA, C. J. C. Evolução da agroindústria canavieira brasileira de 1975 a 1995. Revista Brasileira de Economia, Rio de Janeiro, v. 53, n. 1, p. 69-89, 1999.

SHIKIDA, P. F. A.; STADUTO, J. A. R. (org.). Agroindústria canavieira no Paraná: análises, discussões e tendências. Cascavel: Coluna do Saber, 2005, 167 p. V. 1.

SHIKIDA, P. F. A.; ALVES, L. R. A. Panorama estrutural, dinâmica de crescimento e estratégias tecnológicas da agroindústria canavieira paranaense. Nova Economia, Belo Horizonte, v. 11, n. 2, p. 123-149, 2001.

SHIKIDA, P. F. A; VIAN, C. E. F. de.; LIMA, R. A. S. de.; DAHMER, V. S. Concentração na agroindústria canavieira paranaense pós-desregulamentação setorial. Informações Econômicas (On-line), v. 38, p. 55-67, 2008.

SHIKIDA, P. F. A.; AZEVEDO, P. F. de; VIAN, C. E. de F. Desafios da agroindústria canavieira no Brasil pós-desregulamentação: uma análise das capacidades tecnológicas. Revista de Economia e Sociologia Rural, Piracicaba, v. 9, n. 3, p. 599-628, 2011.

SHIKIDA, P. F. A. Evolução e fases da agroindústria canavieira no Brasil. Revista de Política Agrícola, ano XXIII, n. 4, p. 43-57, 2014.

STADUTO, A. R. S.; SHIKIDA, P. F. A.; BACHA, C. J. C. Alteração na composição da mão de obra assalariada na agropecuária brasileira. Agric. São Paulo, São Paulo, v. 51, n. 2, p. 57-70, 2004.

UNICA. União da Indústria de Cana-de-Açúcar. Unicadata. Produção. Disponível em: http://www.unicadata.com.br/historico-de-producao-e-oagem.php?idMn=32\&tipoHistorico=4 Acesso em: 15 jan. 2019 a.

UNICA. União da Indústria de Cana-de-Açúcar. Unicadata. Exportação e importação. Disponível em: http://www.unicadata.com.br/listagem.php?idMn=24. Acesso em: 14 jan. 2019b.

VIAN, C. E. F.; BELIK, W. Os desafios para a reestruturação do complexo agroindustrial canavieiro do Centro-Sul. Economia, Niterói, RJ, v. 4, n. 1, p. 153-194, 2003.

VIAN, C. E. F.; MORAES, M. A. F. D. de; GONÇALVES, D. B. Progresso técnico, relações de trabalho e questões ambientais na agroindústria canavieira. In: CONGRESSO BRASILEIRO DE ECONOMIA E SOCIOLOGIA RURAL, 44., 2006, Fortaleza. Anais [...]. Fortaleza, 2006. 